\title{
Dorsal Medial Habenula Regulation of Mood- Related Behaviors and Primary Reinforcement by Tachykinin-Expressing Habenula Neurons
}

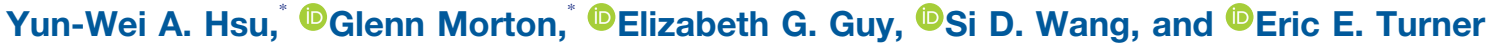 \\ DOI:http://dx.doi.org/10.1523/ENEURO.0109-16.2016 \\ Center for Integrative Brain Research, Seattle Children's Research Institute, Seattle, Washington 98101
}

\begin{abstract}
Animal models have been developed to investigate aspects of stress, anxiety, and depression, but our understanding of the circuitry underlying these models remains incomplete. Prior studies of the habenula, a poorly understood nucleus in the dorsal diencephalon, suggest that projections to the medial habenula $(\mathrm{MHb})$ regulate fear and anxiety responses, whereas the lateral habenula $(\mathrm{LHb})$ is involved in the expression of learned helplessness, a model of depression. Tissue-specific deletion of the transcription factor Pou4f1 in the dorsal $\mathrm{MHb}(\mathrm{dMHb})$ results in a developmental lesion of this subnucleus. These $\mathrm{dMHb}$-ablated mice show deficits in voluntary exercise, a possible correlate of depression. Here we explore the role of the $\mathrm{dMHb}$ in mood-related behaviors and intrinsic reinforcement. Lesions of the $\mathrm{dMHb}$ do not elicit changes in contextual conditioned fear. However, dMHb-lesioned mice exhibit shorter immobility time in the tail suspension test, another model of depression. dMHb-lesioned mice also display increased vulnerability to the induction of learned helplessness. However, this effect is not due specifically to the dMHb lesion, but appears to result from Pou4f1 haploinsufficiency elsewhere in the nervous system. Pou4f1 haploinsufficiency does not produce the other phenotypes associated with $\mathrm{dMHb}$ lesions. Using optogenetic intracranial self-stimulation, intrinsic reinforcement by the $\mathrm{dMHb}$ can be mapped to a specific population of neurokinin-expressing habenula neurons. Together, our data show that the $\mathrm{dMHb}$ is involved in the regulation of multiple mood-related behaviors, but also support the idea that these behaviors do not reflect a single functional pathway.
\end{abstract}

Key words: fear conditioning; habenula; interpeduncular nucleus; learned helplessness; substance P

\section{Significance Statement}

Our current understanding of neural circuits regulating mood states, such as fear and depression, is fragmentary. Recently, interest has grown in how the habenula, a poorly understood nucleus providing descending inputs to the tegmentum and raphe, may affect these behavioral states. We have used mouse genetic models to study part of this system, the dorsal medial habenula $(\mathrm{dMHb})$. Here we report that the $\mathrm{dMHb}$ is not, as previously proposed, required for normal acquisition of a conditioned fear response. Mice with genetic lesions of the $\mathrm{dMHb}$ show some profound effects in mood-related tests, but cannot be described strictly as "depressed" or "resilient", suggesting that at the circuit level, models of affective states are complex and do not report identical phenomena.

\section{Introduction}

The habenula is a poorly understood brain nucleus lying dorsal to the thalamus. Recently, a series of studies has

Received May 5, 2016; accepted June 22, 2016; First published July 01, 2016. The authors report no conflict of interest. begun to explore the role of the habenula in behaviors related to mood regulation and stress. The habenula is divided into lateral habenula (LHb) and medial habenula 
$(\mathrm{MHb})$ subnuclei, and the $\mathrm{MHb}$ can be further subdivided into a dorsal part $(\mathrm{dMHb})$, containing excitatory neurons characterized by the expression of the tachykinin gene Tac1, encoding the neuropeptide substance P (SP), and a ventral part (vMHb), which contains glutamatergic neurons that also produce acetylcholine (Quina et al., 2009; Hsu et al., 2013). Anatomical studies have demonstrated that these subnuclei have distinct neural inputs and downstream targets in the brainstem. Past experiments have generally performed lesions of the entire habenula or its major output tract, the fasciculus retroflexus, and have assigned a wide variety of behavioral functions to the habenula (Lecourtier and Kelly, 2007), but this approach cannot resolve the specific functions of the habenula subnuclei.

Recent experiments targeting the specific input pathways from the septal nuclei to the $\mathrm{vMHb}$ and $\mathrm{dMHb}$ have implicated these circuits in the regulation of anxiety and fear responses, respectively (Yamaguchi et al., 2013). Nonetheless, it remains to be determined whether the $\mathrm{MHb}$ subnuclei are directly involved in the expression of anxiety and fear responses. A pathway through the $\mathrm{LHb}$ has recently been shown to be involved in the expression of learned helplessness (B. Li et al., 2011; K. Li et al., 2013), a model of depression in which animals previously exposed to an inescapable aversive stimulus show diminished escape behavior when the stimulus is avoidable (Maier, 1984; Maier and Watkins, 2005; Duman, 2010). The LHb has well established roles in reward and aversive functioning (Hikosaka, 2010; Proulx et al., 2014). The role of the LHb in mediating depression-like behaviors may thus be related to its roles in punishment (Matsumoto and Hikosaka, 2009), and aversion (Lammel et al., 2012; Stamatakis and Stuber, 2012). Although the MHb has distinct input and output circuitry from the LHb, recent evidence has shown that the $\mathrm{MHb}$ may also play a role in regulation of mood-related behaviors. Recently we have shown that mice with a developmental ablation of the $\mathrm{dMHb}$, generated by targeted deletion of the transcription factor Pou4f1 ( $\mathrm{dMHb}^{\mathrm{CKO}}$ mice), exhibit reduced voluntary wheelrunning activity (WRA), a possible correlate of depression (Hsu et al., 2014). In addition, in contrast to the aversive

This work was supported by National Institute Health Awards R01 MH093667 and R01 DA035838 to E.E.T; Y.-W.A.H. was supported by NIMH Training Award F32MH098498; and E.G.G. was supported by T32-DA007278. We thank Dr. Susan Ferguson for helpful comments on the experimental results and paper, Dr. Fritz Henn for helpful discussions, and Lely Quina for technical assistance. BAC transgenic mice were generated by the Gene Expression Nervous System Atlas (GENSAT) Project, NINDS Contracts N01NS02331 \& HHSN271200723701C to The Rockefeller University (New York, NY). The content is solely the responsibility of the authors and does not necessarily represent the official views of the National Institutes of Health.

*Y.-W.A.H. and G.M. contributed equally to this work.

Correspondence should be addressed to Dr. Eric E. Turner, Center for Integrative Brain Research, Seattle Children's Research Institute, 1900 Ninth Avenue, Mail Stop JMB-10, Seattle, WA 98101. E-mail: eric.turner@ seattlechildrens.org.

DOl:http://dx.doi.org/10.1523/ENEURO.0109-16.2016

Copyright $\odot 2016$ Hsu et al.

This is an open-access article distributed under the terms of the Creative Commons Attribution 4.0 International, which permits unrestricted use, distribution and reproduction in any medium provided that the original work is properly attributed. effect of $\mathrm{LHb}$ stimulation, the $\mathrm{dMHb}$ is intrinsically reinforcing in a self-stimulation paradigm (Hsu et al., 2014), lending additional support for a role for the $\mathrm{dMHb}$ in the maintenance of hedonic states.

In the present study, we investigated whether neurons in the $\mathrm{dMHb}$ regulate mood-related behaviors by testing $\mathrm{dMHb} \mathrm{CKO}^{\mathrm{CKO}}$ mice in models of fear (conditioned fear) and depression (tail suspension test, learned helplessness). We found that mice with $\mathrm{dMHb}$ lesions do not exhibit differences in contextual conditioned fear. The effects of $\mathrm{dMHb}$ ablation in models of depression is significant, but cannot be interpreted simply as "depressed" or "resilient". Using a Cre-driver line that is specific for a tachykinin-expressing subpopulation of $\mathrm{dMHb}$ neurons, we show that activation of these neurons is sufficient to support self-stimulation reinforcement. Collectively, our data show that the $\mathrm{dMHb}$ is involved in the regulation of multiple mood-related behaviors, but also suggest that these behaviors are not mediated by a single neural pathway.

\section{Materials and Methods}

\section{Transgenic mice used in the experiments}

Mice with a tissue-specific null mutation of Pou4f1 in the $\mathrm{dMHb}$ and control littermates used in this study were generated and genotyped as previously described (Hsu et al., 2014). The Pou4f1 mutant mice used and their patterns of Pou4f 1 transcription factor expression are listed in Figure 1A. Two strains of Pou4f1 mutant mice were used: Pou $4 f 1^{\text {tlac } Z}$, a functionally null allele replacing the Pou $4 f 1$ coding sequence with a $\beta$-galactosidase expression cassette (Quina et al., 2005; MGl:3512089), Pou4f1 flox , in which the principal coding exon of Pou $4 f 1$ is flanked by loxP sequences (Hsu et al., 2014, MGl: 5662420). The Pou4f1 flox allele was excised using a Crerecombinase expressing line, Syt6 ${ }^{\mathrm{Cre}}$, (STOCK Tg(Syt6Cre)KI148Gsat/Mmcd), a BAC transgenic generated by the GENSAT project (Gerfen et al., 2013; RRID: MMRRC_032012-UCD), and obtained as cryopreserved sperm from the Mutant Mouse Regional Resource Center of the University of California, Davis. Experimental mice with $\mathrm{dMHb}$ lesions and littermate controls were generated by crossing mice with the genotype Pou4f1 tlacz/+ , Syt6 $6^{\text {Cre/Cre }}$ with Pou4f1 flox/flox mice to yield the genotypes Pou4f1 tlacz/flox, Syt6 Cre/+ $\left(\mathrm{dMHb}^{\mathrm{CKO}}\right)$ and Pou4f1 $1^{\text {flox } /+}$, Syt6 $6^{\mathrm{Cre} /+}\left(\mathrm{dMHb}^{\mathrm{Ctrl}}\right)$ mice in equal ratios. The constitutive null Pou4f1 tlacz allele was used to generate $\mathrm{dMHb} \mathrm{CKO}^{\mathrm{CKO}}$ mice because the generation of animals with complete loss of Pou4f1 expression in the $\mathrm{dMHb}$ is more efficient if one allele is a constitutive null, and thus only one copy of the gene requires Cre-excision The presence of the lac $Z$ gene product $\beta \mathrm{Gal}$ also allows $\mathrm{dMHb}$ neurons to be identified by enzymatic staining or immunofluorescence in cells which no longer express Pou4f1 protein. The $\mathrm{dMHb}^{\mathrm{CKO}}$ mice show a profound loss of neurons in the $\mathrm{dMHb}$ due to postnatal cell death, whereas $\mathrm{dMHb}^{\mathrm{Ctrl}}$ mice do not show detectable loss of $\mathrm{dMHb}$ neurons (Fig. $1 B, C)$.

In order to isolate an effect of Pou4f1 haploinsufficiency in the presence of an intact $\mathrm{dMHb}$, mice that were homozy- 
A

\begin{tabular}{|c|c|c|c|c|}
\hline \multirow{2}{*}{ Genotype } & \multicolumn{2}{|c|}{ Number of Pou4f1 copies } & \multirow{2}{*}{ dMHb status } & \multirow{2}{*}{ Abbreviation } \\
\hline & $\mathrm{dMHb}$ & elsewhere & & \\
\hline Pou4f1 $1^{\text {tlaczflox }}$, Syt6 $6^{\mathrm{Cre} /+}$ & Zero & One & Lesioned & $\mathrm{dMHb} \mathrm{b}^{\mathrm{CKO}}$ \\
\hline Pou4f $1^{\text {floxl+ }}$, Syt6 $6^{\text {Cre/+ }}$ & One & Two & Intact & $\mathrm{dMHb} \mathrm{b}^{\mathrm{Ctr}}$ \\
\hline Pou4f1 ${ }^{\text {tlacZl+}}$, Syt6 $6^{\text {Crel+ }}$ & One & One & Intact & Pou4f1 $1^{+/-}$ \\
\hline Pou $4 \mathrm{f}^{+/+}$, Syt6 ${ }^{\mathrm{Cre} /+}$ & Two & Two & Intact & Pou4f1 $1^{+/+}$ \\
\hline $\mathrm{C} 57 \mathrm{BI} / 6$ & Two & Two & Intact & WT \\
\hline
\end{tabular}
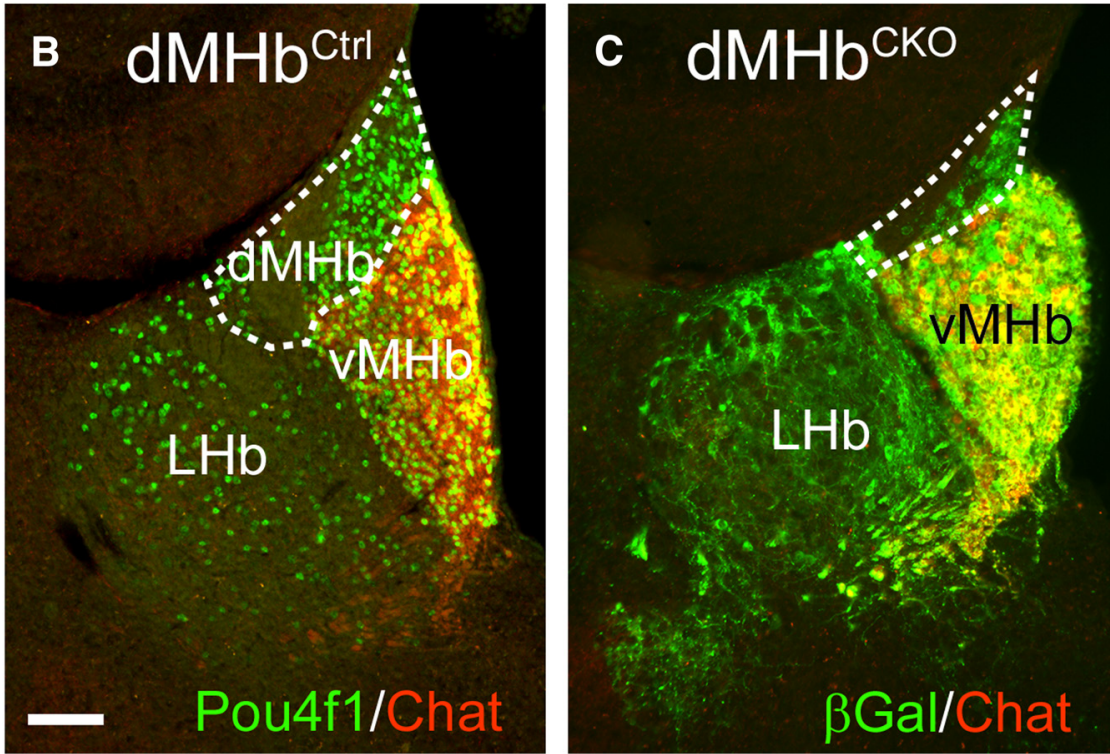

Figure 1. Pou4f1 knock-out models used for analysis of dMHb function. A, Summary of genetic models used to generate dMHb lesions. $\boldsymbol{B}, \boldsymbol{C}$, Coronal sections through the habenula at bregma $-1.58 \mathrm{~mm}$ were stained with antibodies for choline acetyltransferase (Chat) and either Pou4f1 (Brn3a protein) to reveal habenula neurons expressing this factor, or for the lac $Z$ gene product $\beta$ Gal, expressed by the Pou $4 f 1^{\text {tlacZ }}$ allele, which allows the identification of neurons that would normally express Pou $4 \mathrm{f} 1$ in cells in which the gene has been deleted. $\boldsymbol{B}, \mathrm{dMHb}^{\mathrm{Ctrl}}$ mouse with the genotype Pou $4 \mathrm{f1}^{\mathrm{flox} /+} / \mathrm{Syt}^{\mathrm{Cre}}$. Nuclear staining for Pou $4 \mathrm{f} 1$ shows expression in both the $\mathrm{vMHb}$ and $\mathrm{dMHb}$, and scattered expression in the $\mathrm{LHb}$. The $\mathrm{vMHb}$ is distinguished by the expression of Chat, and the Pou4f1-positive, Chat-negative dMHb is circled. Scale bar, $100 \mu \mathrm{m} . \mathbf{C}, \mathrm{dMHb}^{\mathrm{CKO}}$ mouse with the genotype Pou4f1 ${ }^{\text {flox/tlacZ }} / \mathrm{SSt}^{\mathrm{Cre}}$. Staining for lacZ is used to show the extent of the $\mathrm{dMHb}$ lesion in the absence of Pou $4 \mathrm{f} 1$ protein. The extent of the $\mathrm{dMHb}$ is greatly reduced (circle) and only a few $\beta$ Gal-positive, Chat-negative neurons remain in the medial habenula. Neurons of the vMHb, distinguished by Chat expression in $\boldsymbol{A}$ and $\boldsymbol{B}$, are intact in both the $\mathrm{dMHb}^{\mathrm{Ctrl}}$ and $\mathrm{dMHb}^{\mathrm{CKO}}$ mice. The area within the $\mathrm{dMHb}$ that is not stained by any of the antibodies used consists of axon tracts of the striae medularis and/or habenula commissure.

gous or hemizygous for Pou4f1 were generated by crossing male mice with the genotype Pou4f1 tlacz/+ , Syt6 Cre/Cre with C57BI/6 female mice to yield the genotypes Pou $4 f 1^{\text {tlacz/+ }}$,

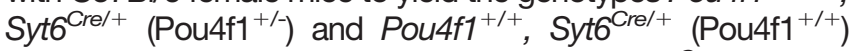
mice in equal ratios. In these genotypes, the Syt6 ${ }^{\text {Cre }}$ allele has no effect because no floxed allele is present, but Syt6 ${ }^{\text {Cre }}$ was incorporated to maintain a consistent genetic background across all lines.

Mice for optogenetic studies of habenula function were generated by using the mouse line Ai32, which conditionally expresses the Channelrhodopsin-2 variant $\mathrm{ChR2}(\mathrm{H} 134 \mathrm{R})$ YFP from a modified floxed-stop Gt(Rosa)26Sor locus (Madisen et al., 2012; RRID:IMSR_JAX:024109). To generate mice expressing ChR2 in tachykinin-expressing neurons in the $\mathrm{dMHb}\left(\mathrm{dMHb} \mathrm{b}^{\mathrm{ChR} 2}\right.$ mice), Ai32 mice were interbred with mice bearing a Tac2 ${ }^{I R E S C r e}$ allele, generated as a part of the Allen Institute Transgenic Characterization Project (Harris et al., 2014; RRID:IMSR_JAX: 021878). Experimental mice from these crosses had the genotype $T a c 2^{I R E S C r e} / A i 32$, and control mice bore the Ai32 allele, without Tac2 IRESCre . Mice expressing ChR2 in the $\mathrm{vMHb}\left(\mathrm{vMHb}^{\mathrm{ChR} 2}\right.$ mice) were generated by interbreeding Ai32 mice with mice bearing a Chat IRESCre allele (Rossi et al., 2011; RRID:IMSR_JAX:006410) and have been previously described (Hsu et al., 2013). Tac2 ${ }^{I R E S C r e}$ and Chat ${ }^{I R E S C r e}$ mice were obtained from Jackson Laboratories. Only male mice were used for the optogenetic experiments.

\section{Analysis of gene expression}

Immunofluorescence methods, including antibodies used to detect the Pou4f1 protein Brn3a (RRID: AB_2314040), choline acetyltransferase (RRID: AB_2079751), substance P (RRID:AB_94639), and $\beta$-galactosidase (not in RRID), have been previously described (Hsu et al., 2014). Rabbit anti-mouse proNeurokininB was obtained from Novus Biologicals (RRID:AB_350516). 


\section{Contextual conditioned fear}

Fear conditioning was performed in a $13 \times 17 \mathrm{~cm}$ compartment (1 compartment of ENV-3013, Med Associates, equipped with grid floor ENV-3013BR). The grid floor was connected to a shock scrambler (ENV-414S, Med Associates) set to $0.40 \mathrm{~mA}$. The Activity Tracking function of Noldus EthoVision XT 10 was used to analyze freezing behavior, which is defined by the absence of observable movement, except for respiration. On day 1, mice were allowed to acclimate to the chamber for $3 \mathrm{~min}$, followed by the delivery of a $1 \mathrm{~s}$ shock every minute for $6 \mathrm{~min}$. To the extent possible, this training procedure was designed to reproduce the methods used in a prior study (Masugi et al., 1999; Yamaguchi et al., 2013). On day 2 of the procedure, animals were returned to the same compartment for 6 min in the absence of shocks in order to assess the contextual conditioned fear response.

We implemented automated scoring of freezing behavior based on a published method using an earlier version of Noldus EthoVision (Pham et al., 2009). Automated analysis of the video derived the image of the subject in each video frame (frame rate $30 \mathrm{~s}^{-1}$, duration $33.33 \mathrm{~ms}$ ). A moving average of the subject image in the previous three video frames was then compared to the current frame, and the subject was determined to be immobile if the image area occupied by the subject in the current frame was changed (displaced, or altered in size or shape) from the moving average by $<0.02 \%$. The activity was scored as freezing if immobility lasted longer than $0.5 \mathrm{~s}$, corresponding to 15 consecutive samples of immobility at the video frame rate of $30 \mathrm{~s}^{-1}$. Reliability of the automated video analysis of freezing behavior was confirmed by manual scoring of test videos of control mice by two human raters blind to the automated scoring results.

\section{Tail suspension test}

The test was performed using inverted U-shaped acrylic stand ( $18 \times 18$ inches, with a 4 inch wide horizontal arm), placed in an isolation chamber with a video camera positioned to include 1.5 inches of the horizontal arm and the entire length of the subject within the field-of-view. At the start of the trial, subjects were suspended from the crossbar using tape placed one inch from the tip of the tail. Although C57BL/6 mice have been observed to climb their tails when performing this test, this behavior was not observed using this apparatus. A 6 min video was recorded and analyzed in Noldus EthoVision XT 10.0 using Activity Tracking. Each recorded video frame was compared to the previous frame (frame rate $30 \mathrm{~s}^{-1}$, duration $33.33 \mathrm{~ms}$ ) and the mouse was determined to be immobile for that period if $<5 \%$ change was observed from one frame to the next.

\section{Learned helplessness and active avoidance}

The learned helplessness protocol consisted of a training session or sessions in which mice were exposed to inescapable shock stimuli, followed by analysis of the learned helplessness response using active avoidance in a twoway shuttle box. Training consisted of 360 shocks of random duration between 1 and $3 \mathrm{~s}$ and random interstimulus interval of $1-15 \mathrm{~s}$, delivered over $\sim 1 \mathrm{~h}$, using
Noldus EthoVision XT 10.0. Active avoidance was assessed using 60 escape trials on the following day, or after 3 weeks to assess the persistence of the learned helplessness response.

Learned helplessness training was performed in a $13 \times$ $17 \mathrm{~cm}$ chamber (either of the main compartments of ENV-3013, Med Associates). Chambers were equipped with conductive grid and rod floors connected to a shock scrambler (ENV-414S, Med Associates) set to $0.40 \mathrm{~mA}$. The active avoidance test was performed in a $42 \times 16.5$ $\mathrm{cm}$ center channel modular shuttle box chamber (ENV010MC, Med Associates) equipped with a video monitoring and analysis system (Noldus EthoVision XT 10.0). The grid floor was connected to the same scrambler used for training and set to $0.40 \mathrm{~mA}$. Sixty escape trials were performed, each consisting of a $4.5 \mathrm{kHz}$ tone followed by a shock. The tone preceded the onset of the shock by $2 \mathrm{~s}$ and continued until the shock event stopped. The maximum duration of each shock was $4 \mathrm{~s}$, and the shock could be avoided by crossing to the opposite side of the compartment during the tone, or stopped by crossing during the shock. A random intertrial interval of 19-29 s was used between trials. Latency to escape was scored as 0 if the animal successfully escaped during the tone before onset of the shock. Otherwise, latency time was calculated from shock onset to the time of escape. A maximum score of 4 was given if the animal failed to escape the shock. The mean latency to escape was calculated over the 60 trials for each mouse.

Over the course of the experiments, we observed that a small number of mice adopted an unintended strategy for shock avoidance in which they straddled the midline of the shuttle box. This behavior caused the video analysis to dither and falsely report a very high frequency of midline crossings, which was easily identified on analysis of the data. The shuttle box arenas defined in the video analysis software were modified in later experiments such that the mouse was required to travel at least $4 \mathrm{~cm}$ beyond the midline in order to avoid or terminate the shock. This modification somewhat increased escape latency because of the increased distance traveled. Cohorts of $10 \mathrm{C} 56 \mathrm{BI} / 6$ male mice were used to assess the effect of this change in the arena boundaries on the measurement of the learned helplessness response. Significant differences were observed between trained and naïve animals using both arena structures.

\section{Accelerating rotarod}

A specialized apparatus (Rotamex-5, Columbus Instruments) was used to test rotarod performance as previously described (Hsu et al., 2014). Briefly, before testing all mice were trained on a fixed-speed protocol at $4 \mathrm{rpm}$ until they could stay on the rod for $30 \mathrm{~s}$. On the same day as the training sessions, mice underwent four $5 \mathrm{~min}$ accelerating rotarod trials. In each trial, the rotarod accelerated from 4 to $40 \mathrm{rpm}$ at the rate of $1 \mathrm{rpm}$ every $8 \mathrm{~s}$, then remained at $40 \mathrm{rpm}$ until the end of the trial. The principal outcome was the time (latency) until the mouse fell from the rod. Mice were given at least 15 min of rest in between 
each trial. To calculate the average latency to fall for each mouse, the lowest of four values was discarded.

\section{Optogenetic intracranial self-stimulation}

Intracranial self-stimulation (ICSS) reinforcement by the $\mathrm{dMHb}$ was tested in an operant chamber (ENV-307W, Med Associates) equipped with two nosepoke receptacles (ENV-313W, Med Associates). Responses were recorded through four training and four reversal sessions.

\section{Training sessions}

Mice underwent four 45 min ICSS sessions in which a randomly assigned active nose-poke receptacle was associated with the delivery of laser stimulation to the $\mathrm{dMHb}$ via an implanted fiber optic cannula (above), and the inactive receptacle did not deliver a stimulus. A 1:1 fixed response-reward ratio was used. The reward consisted of a $2 \mathrm{~s}$ train of $25 \mathrm{~ms}$ light pulses, delivered at $20 \mathrm{~Hz}$ and 8 $\mathrm{mW}$ with a $473 \mathrm{~nm}$ laser, followed by a $2 \mathrm{~s}$ time-out period. Nose pokes during the period of laser stimulation and time-out were recorded but did not trigger a reward. Nose pokes on the inactive receptacle were also recorded.

\section{Reversal sessions}

The reinforcing effect of ICSS was confirmed in four reversal sessions during which the active receptacle was switched to the opposite side, using the same session structure.

\section{Real-time place preference}

Real-time place preference (RTPP) studies were conducted in a two-chamber place-preference box (ENV010MC, Med Associates) in which mice received light stimulation in one side, and could move freely between compartments. Recording and laser stimulation were controlled with EthoVision XT using center point tracking. Sessions were initiated by placing the mouse in the center of the apparatus. The mice were then given free access to both chambers for $15 \mathrm{~min}$. When the mouse entered the active chamber, the $473 \mathrm{~nm}$ laser was activated, delivering $25 \mathrm{~ms}$ light pulses at a $20 \mathrm{~Hz}$ and $8 \mathrm{~mW}$ of total power continuously until the mouse crossed over to the inactive chamber. Conversely, upon entering the inactive chamber, the laser remained off until the mouse entered the active chamber. Active and inactive chamber occupancy and total distance traveled were then calculated for each 5 min interval of the 15 min session.

\section{General statistical methods}

Statistical analyses were conducted using unpaired twotailed $t$ tests, two-way ANOVA or two-way repeatedmeasures ANOVA, with Tukey's or Bonferroni's post hoc analyses in GraphPad Prism 6 (GraphPad Software). Results are presented as mean \pm SEM. We also considered that in this paper and in a prior paper (Hsu et al., 2014), we compared $\mathrm{dMHb}^{\mathrm{CKO}}$ mice and controls in multiple behavioral models that use a motor output measure as a model of depression/behavioral despair. These tests include learned helplessness, the persistence of learned helplessness, and the tail suspension test in the present study, and the forced swim test in the prior study. In the prior study, we also interpreted a deficit in rotarod function as possibly related to behavioral despair. Given that five independent tests were applied, Bonferroni correction for the number of tests suggests that a threshold significance value of $p<0.01$ rather than $p<0.05$ should be used. Using this more stringent standard, the effect of genotype is still significant for learned helplessness, persistence of learned helplessness, tail suspension, and rotarod tests. The effect in the forced swim test was not significant at $p<0.05$.

\section{Results}

\section{The conditioned fear response is not affected by developmental loss of $\mathrm{dMHb}$ neurons}

Recently, lesion studies of the specific septal inputs to the dorsal and ventral $\mathrm{MHb}$ have shown that the septohabenular pathway is involved in the regulation of anxiety and fear (Yamaguchi et al., 2013). Specifically, lesions of septal inputs to the $\mathrm{dMHb}$ increased freezing behavior in the training phase of a conditioned fear paradigm. (Contextual conditioned fear per se was not tested). To test for direct involvement of the $\mathrm{dMHb}$ in fear conditioning we assessed fear acquisition and the contextual fear response using $\mathrm{dMHb}^{\mathrm{CKO}}$ mice and controls. The $\mathrm{dMHb} \mathrm{b}^{\mathrm{CKO}}$ mouse bears a dMHb-specific deletion of the Pou4f1 coding sequence, and shows a nearly complete developmental loss of $\mathrm{dMHb}$ neurons (Fig. 1). Both the $\mathrm{dMHb}^{\mathrm{Ctrl}}$ and $\mathrm{dMHb}^{\mathrm{CKO}}$ mice exhibited the same amount of freezing on the training day (day1) during shock administration (two-way ANOVA; genotype $\times$ trial, effect of genotype: $F_{(1,20)}=0.11, p=0.74$; Fig. $2 A$, time 4-9 min), and time spent in freezing increased with each subsequent shock administration (effect of trial: $F_{(5,100)}=18.48, p<0.0001$ ). Contextual fear response was tested on day 2 by placing the mice in the same environment without shock administration (Fig. 2B). Both genotypes exhibited the same amount of freezing (two-way ANOVA; effect of genotype: $F_{(1,20)}=0.15, p=0.70$ ), with increasing freezing behavior as the test progressed (effect of trial: $F_{(5,100)}=8.45, p<$ $0.0001)$. Finally, we examined the time course for the extinction of conditioned fear response. Fear extinction was tested over 3 subsequent days of exposure to the environment without shock stimuli (Fig. 2C). The freezing response gradually diminished in a similar manner for both genotypes (two-way ANOVA; effect of genotype: $F_{(1,20)}=0.20, p=0.66$; effect of day: $F_{(2,40)}=21.91, p<$ $0.0001)$. Post hoc analyses revealed that both the $\mathrm{dMH}-$ $b^{\mathrm{Ctrl}}$ and $\mathrm{dMHb}^{\mathrm{CKO}}$ mice spent significantly less time freezing starting at $2 \mathrm{~d}$ post-training. Thus, we conclude that $\mathrm{dMHb}$ ablation has no significant effect on acquisition of the fear response, and no effect on contextual conditioned fear or its extinction.

\section{Pou4f1 gene dosage affects learned helplessness in an active avoidance model}

Another model for assessing depression-like behavioral changes in rodents is learned helplessness. In this paradigm, animals are exposed to stress in the form of inescapable shocks, and the uncontrollability of the stressful stimulus is thought to generate a learned helplessness 
A

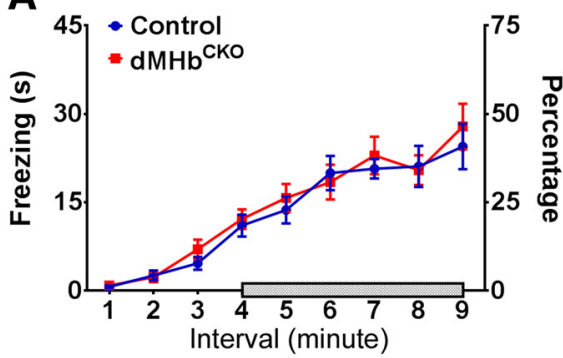

C

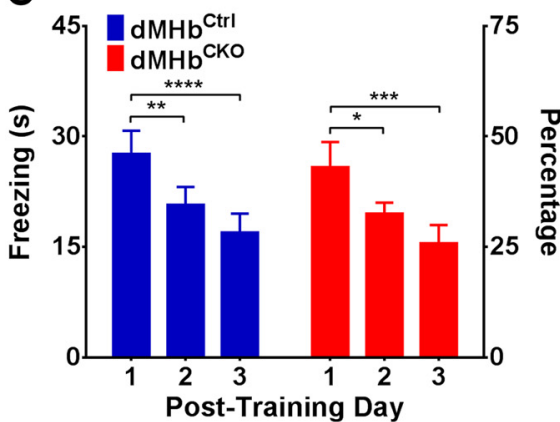

B

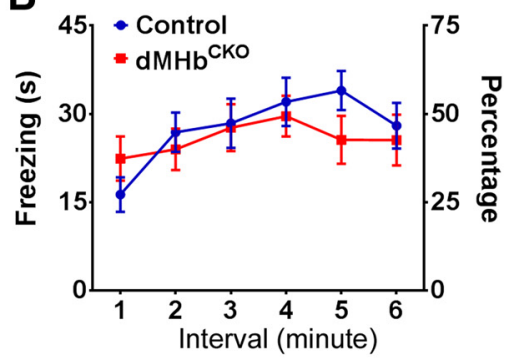

Figure 2. Conditioned fear response in $\mathrm{dMHb}^{\mathrm{CKO}}$ mice. $\boldsymbol{A}$, Training session: time spent in freezing behavior in 1 min intervals during 3 min of acclimation, followed by six intervals preceded by the delivery of a $1 \mathrm{~s}$ shock, is shown. Shaded bar shows the period of shock administration. $\boldsymbol{B}$, Contextual conditioned fear response: on the testing day, the time spent in freezing behavior was assessed in the same environment as the training session, but without shock delivery, to evaluate the conditioned fear response. $\mathrm{dMHb}^{\mathrm{CKO}}$ and $\mathrm{dMHb}^{\mathrm{Ctrl}}$ mice exhibited the same amount of freezing during both the training and testing day. $\boldsymbol{C}$, Extinction of the conditioned fear response: time spent in freezing behavior during 3 subsequent days of testing is shown. The conditioned fear response showed gradual extinction in the absence of further shock stimuli. $* p=0.033, * * p=0.0082, * * * p=0.0003$, and $* * * * p<0.0001$, significant difference between days for these genotypes. $N=12 \mathrm{dMHbCtrl}$ and $10 \mathrm{dMHb}{ }^{\mathrm{CKO}}$ mice.

behavior in which animals subsequently fail to escape an aversive stimulus in a different environment (Maier, 1984). Like the forced swim test (FST) and tail suspension test (TST), learned helplessness has been used to predict antidepressant response (Duman, 2010). In the implementation of learned helplessness used here, mice were administered inescapable shocks during one training session in an apparatus used exclusively for the training. Mice were then tested $24 \mathrm{~h}$ later for active avoidance in a separate two-way shuttle box to assess the learned helplessness response (Chourbaji et al., 2005). The mice were also tested 3 weeks later to determine the persistence of learned helplessness.

Both $\mathrm{dMHb}^{\mathrm{CKO}}$ and $\mathrm{dMHb}^{\mathrm{Ctrl}}$ mice that received inescapable shocks during training took longer to escape the shocked compartment on the testing day compared to unshocked mice (two-way ANOVA; genotype $\times$ treatment, effect of treatment: $F_{(1,47)}=49.50, p<0.0001$; Fig. $3 A$ ), and mice also showed a significant difference in escape latency between genotypes (effect of genotype: $\left.F_{(1,47)}=11.39, p=0.0015\right)$. Post hoc analyses indicate that although no difference was observed between the $\mathrm{dMHb}^{\mathrm{CKO}}$ and $\mathrm{dMHb}^{\mathrm{Ctrl}}$ mice that did not receive inescapable shock training $(p=0.70), \mathrm{dMHb}^{\mathrm{CKO}}$ mice that received inescapable shocks had longer escape latency compared to shocked $\mathrm{dMHb}^{\mathrm{Ctrl}}$ mice $(p=0.0029)$. Thus, the genetic lesion in $\mathrm{dMHb}^{\mathrm{CKO}}$ mice rendered them more vulnerable to the development of learned helplessness behavior. The learned helplessness phenotype persisted
3 weeks after shock training (Fig. 3B), and there was a significant difference attributable to shock administration $\left(F_{(1,47)}=15.38, p=0.0003\right)$ and genotype $\left(F_{(1,47)}=16.99\right.$, $p=0.0002)$. Post hoc analyses suggest that this is due to the persistence of learned helplessness response retained by the learned helplessness $\mathrm{dMHb}^{\mathrm{CKO}}$ mice. We also examined the effect of extended training and determined that learned helplessness response of the $\mathrm{dMHb}$ $\mathrm{CKO}$ and $\mathrm{dMHb}^{\mathrm{Ctrl}}$ mice converged after $3 \mathrm{~d}$ of inescapable shock administration $\left(t_{(18)}=1.20, p=0.24\right.$; Fig. $\left.3 C\right)$.

Although the most obvious explanation for the sensitization to learned helplessness in $\mathrm{dMHb}^{\mathrm{CKO}}$ mice is the nearly complete loss of dMHb neurons in these animals, these mice possess one conditional Pou4f1 allele $\left(P o u 4 f 1^{\text {flox }}\right.$ ) and one Pou4f1 null allele (Pou4f1 ${ }^{\text {tlacz}}$; see Materials and Methods), and are thus globally hemizygous for Pou4f1. To determine whether the observed learned helplessness phenotype resulted from the developmental loss of dMHb neurons, or could be a general effect of Pou4f1 haploinsufficiency, we also examined

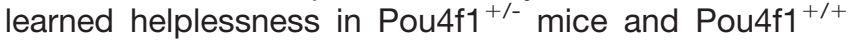
controls. After $1 \mathrm{~d}$ of inescapable shock administration, Pou $4 \mathrm{f} 1^{+/-}$mice took longer to escape the shocked compartment during the active avoidance test compared to Pou4f1 ${ }^{+/+}$mice $\left(t_{(30)}=2.97, p=0.0059\right.$; Fig. 3D). As observed in the $\mathrm{dMHb}^{\mathrm{CKO}}$ mice, the learned helplessness response persisted in the Pou $4 \mathrm{f} 1^{+/-}$mice 3 weeks after the initial shock administration $\left(t_{(30)}=3.78, p=0.0007\right.$; 
A

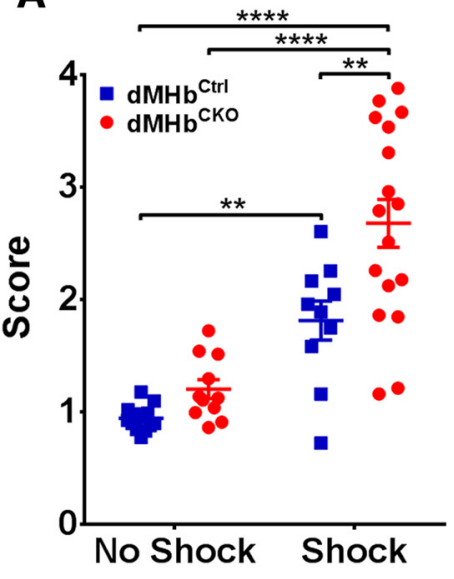

B

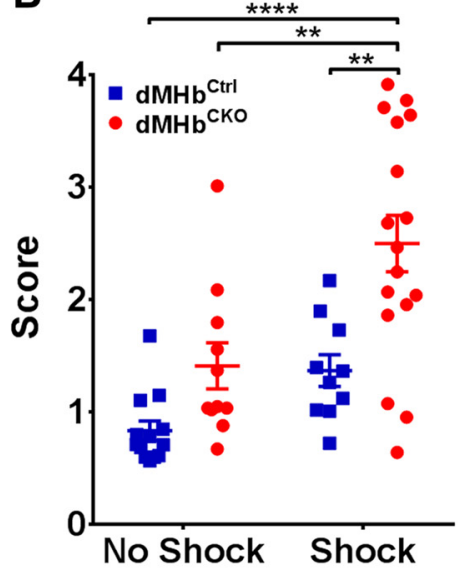

C

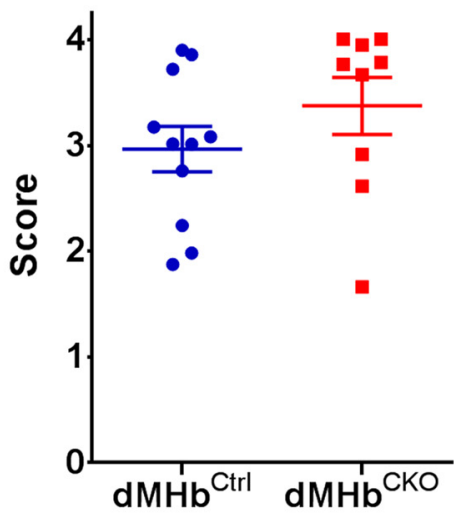

D

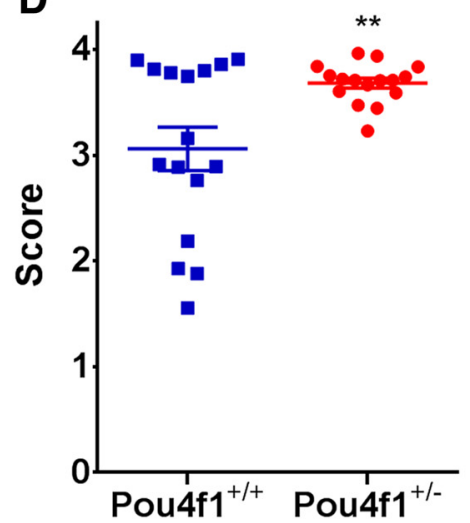

E

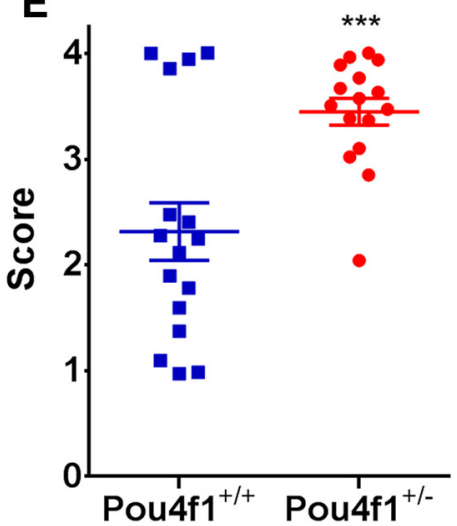

Figure 3. Learned helplessness assessed by active avoidance in $\mathrm{dMHb}^{\mathrm{CKO}}$ mice. $\boldsymbol{A}$, Learned helplessness response: the mean latency to escape in the shuttle box following $1 \mathrm{~d}$ of inescapable shock training, or exposure to the training chamber without a shock, is shown. Both the $\mathrm{dMHb} \mathrm{CKO}^{-}$ and $\mathrm{dMHb}^{\mathrm{Ctrl}}$ mice that received shocks during training showed increased latency to escape, but $\mathrm{dMHb}^{\mathrm{CKO}}$ mice exhibited a stronger effect. $* * p$ $<0.01$, ****p $<0.0001$ for difference between groups indicated. $\boldsymbol{B}$, Persistence of the learned helplessness response: the mean latency to escape was reassessed for the cohort shown in $\boldsymbol{A} 3$ weeks after inescapable shock training. $\mathrm{dMHb}^{\mathrm{Ctrl}}$ mice that received inescapable shocks returned to near-baseline escape times. $\mathrm{dMHb}^{\mathrm{CKO}}$ mice that received inescapable shocks retained the learned helplessness behavior. $* * p<0.01$ and $* * * * p<0.0001$, significant difference between groups. $N=13$ no-shock dMHbCtrl, 10 shocked dMHb $\mathrm{drl}^{\mathrm{Crl}}, 11 \mathrm{no}-\mathrm{shock} \mathrm{dMHb} \mathrm{bKO}^{\mathrm{C}}$, and 17 shocked $\mathrm{dMHb}^{\mathrm{CKO}}$ mice. $\boldsymbol{C}$, Convergence of learned helplessness response with extended training: the mean latency to escape was assessed after $3 \mathrm{~d}$ of inescapable shock training in a different cohort of mice. Both the $\mathrm{dMHb}^{\mathrm{CKO}}$ and $\mathrm{dMHb} \mathrm{b}^{\mathrm{Ctrl}}$ mice received shocks during the training. The prolonged training increased escape latency for both genotypes when assessed by active avoidance $1 \mathrm{~d}$ after the final training session. $N=$ $11 \mathrm{dMHb}^{\mathrm{Ctrl}}$ and $9 \mathrm{dMHb}^{\mathrm{CKO}}$ mice. $\boldsymbol{D}, \boldsymbol{E}$, Assessment of learned helplessness in a separate cohort of Pou4f1 hemizygous mice. $\boldsymbol{D}$, Learned helplessness response: the mean latency to escape in the shuttle box following $1 \mathrm{~d}$ of inescapable shock training is shown. Both the Pou $4 \mathrm{f} 1^{+/-}$ and Pou $4 \mathrm{f} 1^{+/+}$(wild-type) mice received shocks during the training. Pou $4 \mathrm{f} 1^{+/-}$mice exhibited increased latency to escape relative to Pou4f1 ${ }^{+/+}$ mice, i.e., were more susceptible to the induction of learned helplessness. $* * p=0.0059$, significant difference between the genotypes. $\boldsymbol{E}$, Persistence of learned helplessness response: the mean latency to escape was reassessed for the cohort shown in $\boldsymbol{D} 3$ weeks after inescapable shock training. The Pou $4 \mathrm{f}^{+/-}$mice showed persistently elevated escape latency relative to Pou $4 \mathrm{f} 1^{+/+}$mice. $* * * p=0.0007$, significant difference between the genotypes. Minor modifications to the active avoidance protocol used in $\boldsymbol{D}$ and $\boldsymbol{E}$, resulting in somewhat longer escape times, are described in Materials and Methods.

Fig. 3E). We conclude that the increased susceptibility to induction of learned helplessness behavior in Pou4f1deficient mice is not exclusively dependent on the ablation of $\mathrm{dMHb}$ neurons.

\section{dMHb-lesioned mice exhibit prolonged escape behavior in the tail suspension test}

Previously reported experiments have shown that developmental loss of the $\mathrm{dMHb}$ does not increase immobility time during the forced swim test, a model of stress re- sponse and depression (Duman, 2010; Hsu et al., 2014). Here, we assessed the behavior of $\mathrm{dMHb}^{\mathrm{CKO}}$ mice using another model of depression, the TST (Steru et al., 1985; Cryan et al., 2005). Rodents suspended by their tails will initially struggle to escape, but eventually stop and become immobile. The time that the mice spend immobile in a trial of fixed duration is recorded as the principal outcome of the test. $\mathrm{dMHb}^{\mathrm{CKO}}$ mice showed lower immobility time compared to $\mathrm{dMHb}^{\text {Ctrl }}$ mice during the 6 min test $\left(t_{(18)}=3.47, p=0.0027\right.$; Fig. $\left.4 A\right)$. 
A

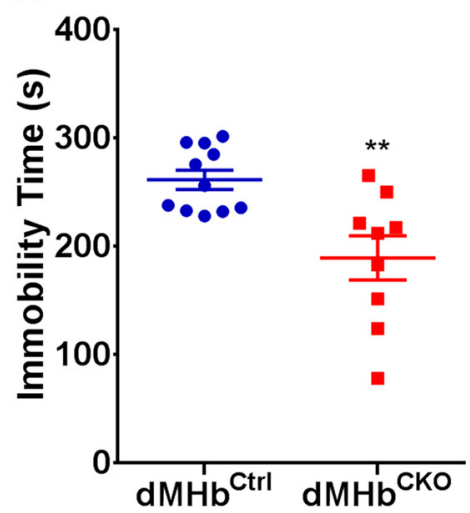

B

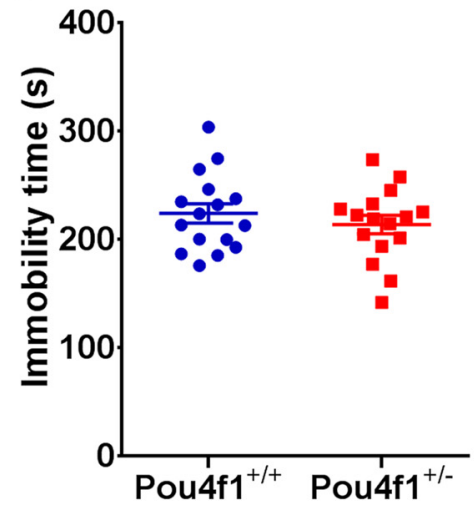

C

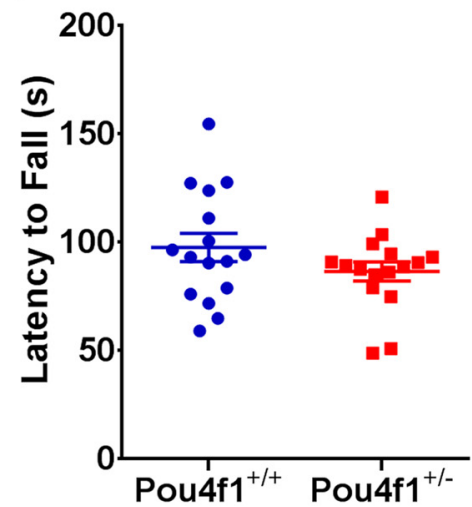

Figure 4. TST immobility time in $\mathrm{dMHb}^{\mathrm{CKO}}$ and Pou4f1 hemizygous mice, and affect of hemizygosity on rotarod performance. $\boldsymbol{A}$, Time spent immobile in the TST is shown for $\mathrm{dMHb}^{\mathrm{CKO}}$ and $\mathrm{dMHb}^{\mathrm{Ctrl}}$ mice. $* * p<0.01$, significance difference between the genotypes. $N=$ $11 \mathrm{dMHbCtrl}$ and $9 \mathrm{dMHb} \mathrm{CKO}^{\mathrm{C}}$ mice. $\boldsymbol{B}$, Time spent immobile in the TST is shown for Pou $4 \mathrm{f1} 1^{+/+}$and Pou4f1 ${ }^{+/-}$mice. Pou4f1 gene dosage did not affect immobility time in the absence of a developmental dMHb lesion. $N=16$ Pou4f1 ${ }^{+/+}$and 16 Pou4f1 ${ }^{+/-}$mice.

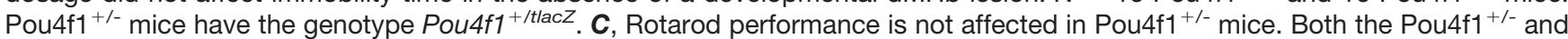
Pou $4 \mathrm{f} 1^{+/+}$mice had similar latency to fall times in this test. $N=16$ of each genotype.

To test whether the TST phenotype could be due to haploinsufficiency of Pou4f1, rather than the $\mathrm{dMHb}$ lesion observed in $\mathrm{dMHb}^{\mathrm{CKO}}$ mice, we also performed the TST on cohorts of matched Pou $4 \mathrm{f}^{+/-}$and Pou $4 \mathrm{f} 1^{+/+}$mice (Fig. 4B). No difference in TST immobility time was observed between Pou $4 \mathrm{f} 1^{+/-}$and Pou $4 \mathrm{f} 1^{+/+}$mice $\left(t_{(30)}=\right.$ $0.84, p=0.41)$. Thus, we conclude that the developmental loss of the $\mathrm{dMHb}$ mediates the reduced TST immobility observed in $\mathrm{dMHb}^{\mathrm{CKO}}$ mice.

\section{Pou4f1 haploinsufficiency does not affect rotarod and voluntary wheel running performance}

A prior study has shown that $\mathrm{dMHb}^{\mathrm{CKO}}$ mice have a deficit in the accelerating rotarod test, with a markedly shortened latency to fall from the device, and a reduction in voluntary WRA (Hsu et al., 2014). Although the rotarod is usually used to assess motor deficits, other tests of motor function in these mice, including open-field locomotion, gait, and balance beam performance, were largely normal (Hsu et al., 2014). For this reason, it was concluded that the deficits in rotarod and WRA in $\mathrm{dMH}^{\mathrm{CKO}}$ mice likely resulted from a loss of motivation or reinforcement, rather than a deficit in motor function per se. Here, however, we have shown that Pou $4 f 1$ haploinsufficiency can contribute to a mood-related phenotype, learned helplessness. Thus, to determine whether Pou4f1 haploinsufficiency affects rotarod performance, we repeated this test in Pou $4 \mathrm{f} 1^{+/-}$and Pou $4 \mathrm{f} 1^{+/+}$mice. Both genotypes have similar fall latency in the rotarod test $\left(t\right.$ test, $t_{(30)}=1.42, p=$ 0.17 ; Fig. $4 C$ ), confirming that the reported deficit in rotarod performance in $\mathrm{dMHb}^{\mathrm{CKO}}$ mice results from the developmental loss of $\mathrm{dMHb}$ neurons, not from Pou4f1 haploinsufficiency.

Experiments to be published elsewhere demonstrate that WRA does not differ significantly between Pou4f1 $1^{+/-}$ and Pou $41^{+/+}$mice (Y.-W. Hsu, H. de la Iglesia and E. Turner unpublished observations), and thus that the WRA deficit in $\mathrm{dMHb}^{\mathrm{CKO}}$ mice is also specifically related to $\mathrm{dMHb}$ ablation.

\section{Tachykinin-expressing dMHb neurons mediate ICSS reinforcement}

The $\mathrm{dMHb}$ is characterized by the expression of the tachykinin genes Tac1 (encoding SP), expressed exclusively in this subnucleus (Fig. 5A; Quina et al., 2009), and Tac2 (encoding NKB), which is expressed in the $\mathrm{dMHb}$ and $\mathrm{vMHb}$ (Fig. 5B). Here we wished to test whether these tachykinin-expressing $\mathrm{dMHb}$ neurons are sufficient to mediate ICSS reinforcement, potentially linking the $\mathrm{MHb}$ to the behavioral effects ascribed to tachykinins and their receptors.

In search of an optogenetic ICSS model, we examined reporter expression driven by a Tac2 ${ }^{I R E S C r e}$ transgenic line generated as part of the Allen Institute Transgenic Characterization Project (Harris et al., 2014). These mice were crossed with a Cre-dependent reporter line, Ai32, that conditionally expresses a ChR2-eYFP fusion protein (Madisen et al., 2012). Surprisingly, reporter expression more strongly resembled that of Tac1 mRNA than Tac2 mRNA, in that it was largely restricted to a subset of neurons in the $\mathrm{dMHb}$ (Fig. $5 \mathrm{C}$ ). Expression of eYFP was rarely observed in the $\mathrm{VMHb}$, as defined by the expression of the cholinergic marker choline acetyltransferase (Fig. 5D). PCR with allele-specific oligos confirmed the correct insertion of the targeted transgene at the Tac2 locus. We note that Allen Institute database in situ hybridization data for Tac2 ${ }^{I R E S C r e}$ crossed with another reporter line, Ai14, shows the same pattern of reporter expression, restricted to the $\mathrm{dMHb}$ (Fig. 5E). Finally, we note that an independently generated $\mathrm{Tac}{ }^{\mathrm{Cre}}$ driver line, generated by replacement of the Tac2 gene rather than targeting of an IRES-Cre to the 3'-untranslated region of the transcript, shows a similar pattern of expression, primarily in the $\mathrm{dMHb}$ (Mar et al., 2012). Consistent with the pattern of marker expression driven by Tac2 $2^{\text {RESCre }}$ in the $\mathrm{dMHb}$, 

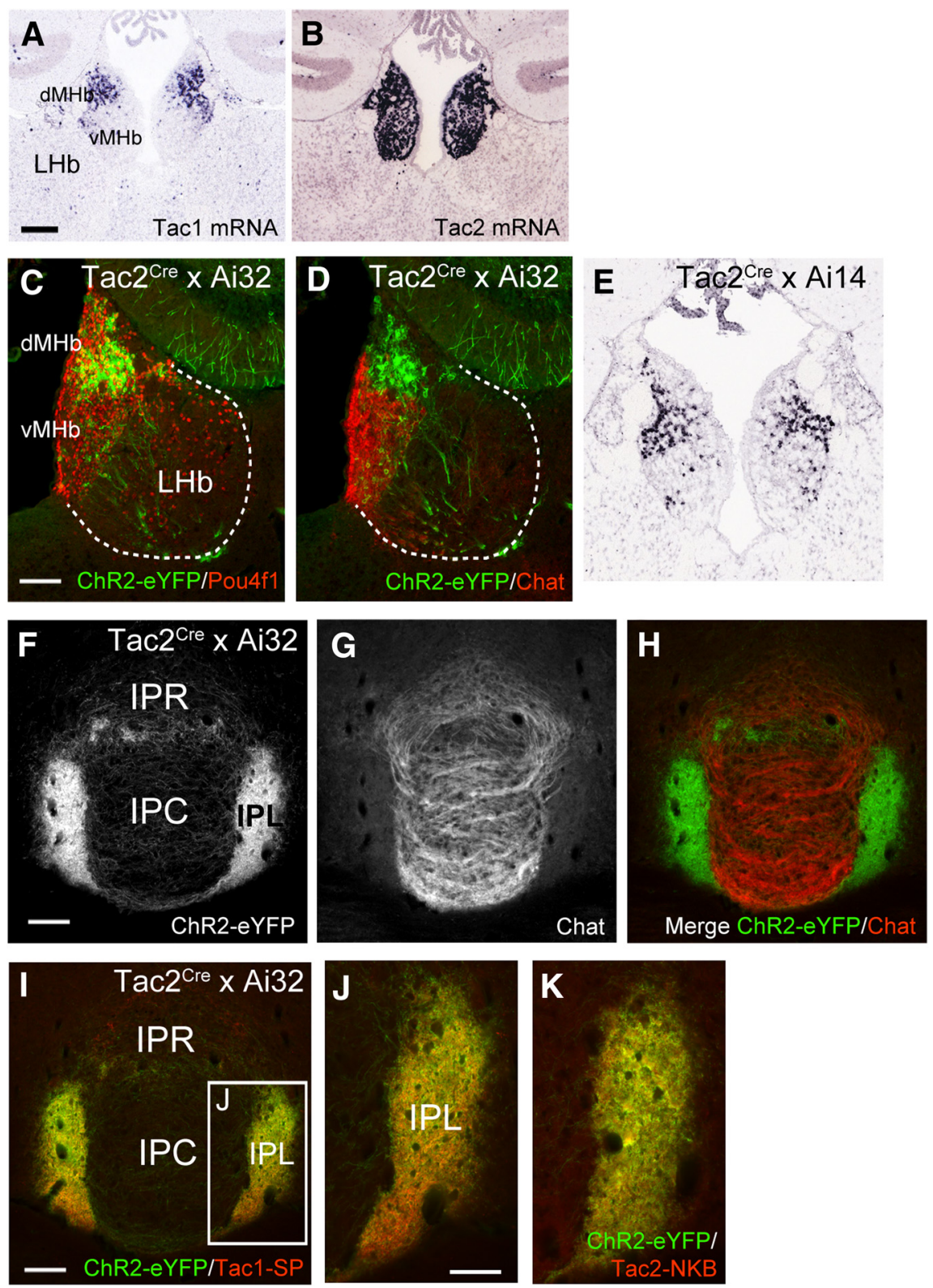

Figure 5. Specific expression of channelrhodopsin in tachykinin-expressing neurons in $\mathrm{dMHb}_{\mathrm{H}} \mathrm{Tac}{ }^{\mathrm{ChR} 2}$ mice. $\boldsymbol{A}, \boldsymbol{B}, \mathrm{Comparison}$ of Tac1 and Tac2 mRNA expression in the habenula; the axial level is approximately bregma $-1.6 \mathrm{~mm}$. Data are derived from the Allen Mouse Brain Atlas. C, $\boldsymbol{D}$, Conditional expression of ChR2-eYFP in Ai32 mice driven by Tac2 $2^{I R E S C r e}$ in the habenula. Dashed lines demarcate the extent of the habenula based on the expression of the nuclear factor Pou $4 \mathrm{f} 1$ (C). Expression is infrequently seen in the $\mathrm{VMHb}$, as defined by the expression of Chat $(\boldsymbol{D})$. $\boldsymbol{E}$, Conditional expression of tdTomato mRNA in Ai14 mice driven by Tac2 ${ }^{\prime R E S C r e}$ in the habenula (Allen Transgenic Mouse Characterization Project). $\boldsymbol{F}-\boldsymbol{H}, \mathrm{ChR} 2$-eYFP labeled fibers terminate predominantly in the lateral part of the interpeduncular nucleus, which receives afferents from the $\mathrm{dMHb}(\boldsymbol{F}, \boldsymbol{H})$; these fibers are largely excluded from the IPR/IPC, which receive fibers mainly from the $\mathrm{VMHb}(\boldsymbol{G})$. $\boldsymbol{I}$, $\boldsymbol{J}$, Colocalization of SP, product of the Tac1 gene, with ChR2-eYFP in the interpeduncular nucleus of dMHb-Tac ${ }^{\mathrm{ChR} 2}$ mice. $\boldsymbol{K}$, Colocalization of neurokinin B, product of the Tac2 gene, with ChR2-eYFP. Scale bars: $\boldsymbol{A}, 200 \mu \mathrm{m} ; \boldsymbol{C}, \boldsymbol{F}, \boldsymbol{I}, 100 \mu \mathrm{m} ; \boldsymbol{J}, 50 \mu \mathrm{m}$.

selective innervation by labeled fibers is found in the lateral nucleus of the IP (IPL; Fig. 5F-H), in which presynaptic $\mathrm{dMHb}$ fibers are marked by the expression of the Tac1 gene product SP (Fig. 5I,J) and the Tac2 gene product NKB (Fig. 5K). Tac2/RESCre -labeled fibers are relatively sparse in the rostral IP (IPR)/caudal IP (IPC) where Chat-immunoreactive fibers originating in the $\mathrm{vMHb}$ are located. It is not known why Tac2 $2^{\text {IRESCre }}$ shows a strong preference for the $\mathrm{dMHb}$ and its efferent target the IPL, but we conclude that Tac2 $2^{\text {RESCre }}$ is a suitable model system for selective manipulation of tachykinin (Tac1/ Tac2) expressing neurons in the $\mathrm{dMHb}$.

To test ChR2 function in Tac2 $2^{\text {IRESCre }}, A i 32\left(\mathrm{dMHb}^{\mathrm{ChR} 2}\right)$ mice, we first evaluated light-evoked neural activity in the 

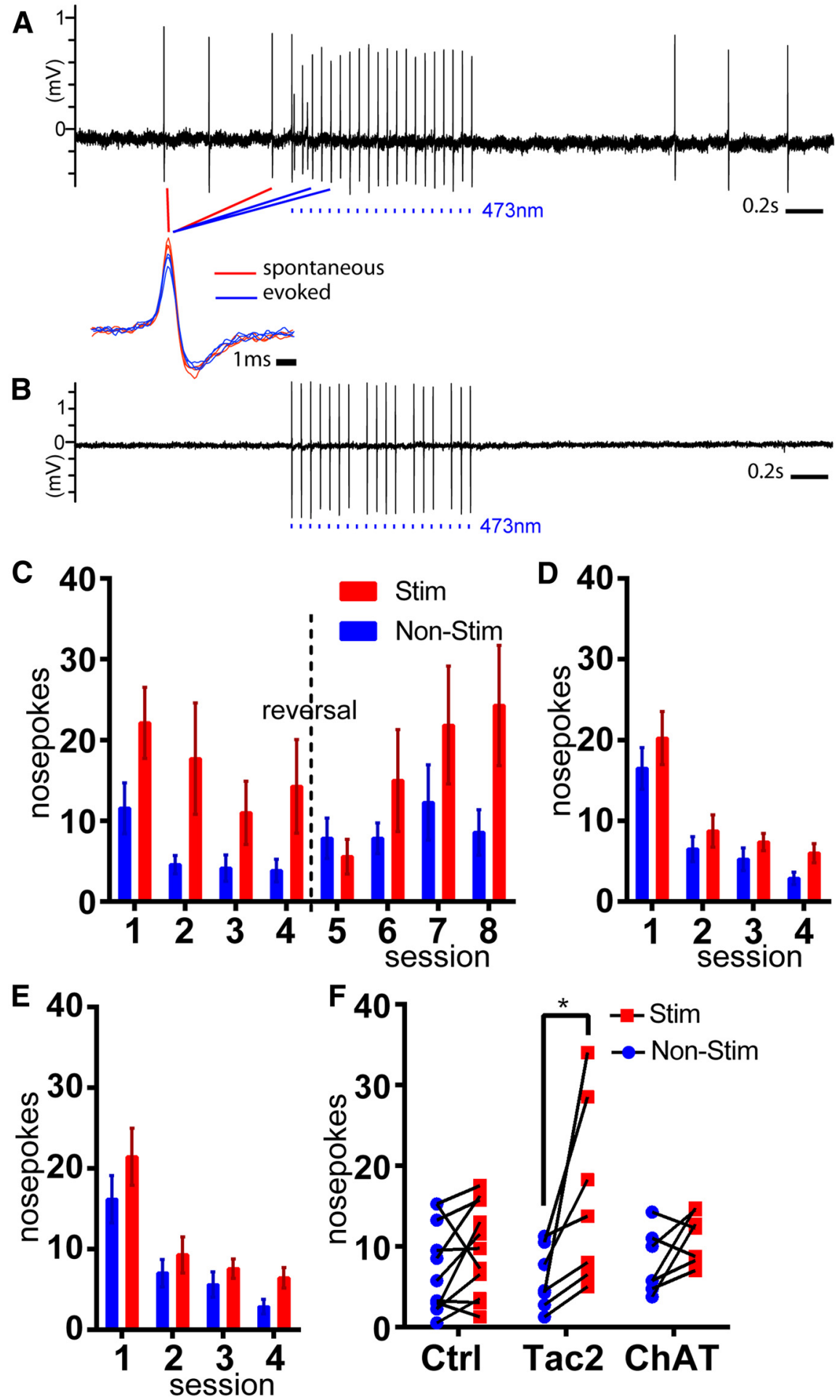

Figure 6. Intrinsic reinforcement mediated by neurokinin-expressing $\mathrm{dMHb}$ neurons. $\boldsymbol{A}, \boldsymbol{B}$, Light entrainment of dMHb neurons expressing Tac2 ${ }^{\mathrm{Cre}}$-driven ChR2. $\boldsymbol{C}$, Optogenetic ICSS in dMHbChR2 mice. Two nose-poke receptacles in each behavioral compartment were randomized to active and inactive at the beginning of the trial. The initial assignment was maintained for days $1-4$ of training, and then reversed for days 5-8 of training (reversal trials). Mice received a $2 \mathrm{~s}$ light stimulation of the dMHb for each nose-poke event in the active receptacle. $\boldsymbol{D}$, ICSS in control mice lacking a Cre-driver; no preference for the active receptacle was observed. $\boldsymbol{E}$, ICSS in vMHb ${ }^{\mathrm{ChR} 2}$ mice; no preference was observed. $\boldsymbol{F}$, Average values for nose-poke events in the inactive and active receptacles over $4 \mathrm{~d}$ of trials for $\mathrm{dMHb}^{\mathrm{ChR} 2}(N=7), \mathrm{vMHb}^{\mathrm{ChR} 2}(N=6)$ and control $(N=11)$ mice. 
$\mathrm{dMHb}$ using cell-attached recording in acute brain slices (Fig. $6 A, B)$. Of the six light-responsive $\mathrm{dMHb}$ neurons sampled, one was spontaneously active at $\sim 4 \mathrm{~Hz}$, one was spontaneously active at $<1 \mathrm{~Hz}$, and four were silent until exposed to light pulses. All six recorded neurons could be entrained with complete fidelity to a train of pulses delivered at $10 \mathrm{~Hz}$; in some neurons entrainment with a $20 \mathrm{~Hz}$ pulse train resulted in omission of some spikes (Fig. 6B). The waveforms of spontaneous and evoked spikes were very similar (Fig. 6A, expanded view).

To test whether $\mathrm{dMHb}$ neurokinin-expressing neurons mediate intrinsic reinforcement, we used an optogenetic ICSS protocol. $\mathrm{dMHb}^{\mathrm{ChR} 2}$ mice were implanted with a bilateral optical fiber cannula positioned just dorsal to the $\mathrm{dMHb}$ (Fig. 7). To determine whether vMHb neurons, identified by the expression of acetylcholine as a cotransmitter, might mediate ICSS reinforcement, we also implanted Chat ${ }^{\mathrm{Cre}}$, Ai32 ( $\left.\mathrm{vMHb}^{\mathrm{ChR} 2}\right)$ mice. The neurons of $\mathrm{VMHb}^{\mathrm{ChR} 2}$ mice were previously shown to have light responses similar to those shown here for $\mathrm{dMHb}^{\mathrm{ChR2}}$ neurons in acute brain slices (Hsu et al., 2013). Littermate mice lacking a Cre driver were implanted with optical fibers and used as controls for both optogenetic genotypes.

ICSS was evaluated in four training sessions in which mice were presented with a two nose-poke receptacles, one of which delivered a $2 \mathrm{~s}$ train of light pulses upon entry, and one of which was inactive. $\mathrm{dMHb}^{\mathrm{ChR} 2}$ mice developed a preference for the active receptacle on the first training day, which persisted through $4 \mathrm{~d}$ of training (Fig. 6C,F). The cohort of $\mathrm{dMHb}^{\mathrm{ChR} 2}$ mice then underwent four sessions in which the active receptacle was reversed. One day (day 5) was required for extinction of the response to the previously active receptacle, and by day 6 of training, a preference for the newly active receptacle was established. In contrast, vMHb ${ }^{\mathrm{ChR} 2}$ mice (Fig. $6 D, F$ ) and control mice (Fig. 6E,F) did not establish a significant preference over $4 \mathrm{~d}$ of training. ICSS using a nose-poke response is not an effective measure of aversion, because both a neutral stimulus and an aversive one may elicit no response. For this reason, we tested possible aversion to light stimulation in $\mathrm{dMHb}^{\mathrm{ChR} 2}$ mice in a real-time place preference paradigm (Hsu et al., 2014). No aversive or reinforcing response to $\mathrm{dMHb}$ stimulation was detected in this paradigm (Fig. 8). We conclude that the reinforcing effect of $\mathrm{MHb}$ stimulation is specifically conferred by activation of neurokinin-expressing $\mathrm{dMHb}$ neurons, and that ICSS is more effective at detecting this effect than place preference.

\section{Discussion}

Fear conditioning, the induction and learning of threat responses in rodents, is a widely used model of human stress-related disorders. Studies of the neural pathways underlying contextual and cued (Pavlovian) fear conditioning have focused on core circuitry involving the amygdala (Dejean et al., 2015; Keifer et al., 2015), with the integration of hippocampal and frontal circuits in contextual conditioning (Maren et al., 2013; Rozeske et al., 2015), and the periaqueductal gray in mediating the freez- ing response. Although the $\mathrm{dMHb}$ is not part of this amygdala-centered circuitry known to be involved in conditioned fear, a recent report suggests involvement of the septohabenular pathway in fear behavior (Yamaguchi et al., 2013). In this study, immunotoxin-mediated cell targeting was used to ablate neurons in the bed nucleus of the anterior commissure (BAC), part of the septal complex, that project specifically to the $\mathrm{dMHb}$. BAC-ablated mice showed increased freezing response during fear training, but the effect on conditioned fear was not reported. Here we have used a contextual conditioning protocol, without a specific cue, to reproduce the original study to the extent possible. Our results demonstrate that the $\mathrm{dMHb}$ is not essential for the acquisition of acute fear or for the contextual conditioned fear response. Further understanding of the septohabenular circuitry may shed light on why the fear response was not affected in our study. It is possible that ablation of the BAC may have effects on fear behavior that are not mediated by the $\mathrm{dMHb}$.

Consistent with our results, lesions of the entire habenula $(\mathrm{MHb}+\mathrm{LHb})$ in mice show no net effect on conditioned fear (Heldt and Ressler, 2006). However, a recent study has shown that cue-conditioned fear is modulated by cannabinoid receptors in the MHb (Soria-Gómez et al., 2015). This effect is attributed to $\mathrm{VMHb}$ neurons that use acetylcholine as a cotransmitter, which are intact in the mice used in the present study (Fig. 1) rather than the $\mathrm{dMHb}$. Thus, to date there is no evidence for a direct role for the $\mathrm{dMHb}$ in fear conditioning.

Here and in a prior study (Hsu et al., 2014), we have examined the effect of $\mathrm{dMHb}$ ablation in several widelyused models of depression, including the Porsolt FST, the TST, the sucrose preference test, and learned helplessness. Ablation of the $\mathrm{dMHb}$ had no discernable effect on the FST (Hsu et al., 2014), yet in the present study, $\mathrm{dMHb}^{\mathrm{CKO}}$ mice show reduced immobility in the conceptually-related TST, a result that could be interpreted as an antidepressant response. These tests are conceptually associated based on the common concept of "behavioral despair", originally applied to the FST, in which rodents initially attempt to escape an adverse situation, and then become passive and relatively immobile. The widely used animal models of depression have been linked to mood states by their face validity and their value in predicting antidepressant responses (Cryan and Mombereau, 2004; Duman, 2010). However, antidepressants work on neurotransmitter systems with broad CNS effects. Because the FST and TST involve different stimuli and different locomotor responses, there is no reason to assume that these tests will always have concordant results in transgenic models that affect specific neural pathways. Supporting this concept, quantitative trait locus analysis of mouse strains that show differential behavior in the TST and FST have mapped both distinct and common gene loci linked to behavior in these tests (Yoshikawa et al., 2002; Tomida et al., 2009).

One strain of genetically altered mice shown to have decreased immobility time (antidepressant effect) in the TST and FST are those with a specific deletion of the Tac1 

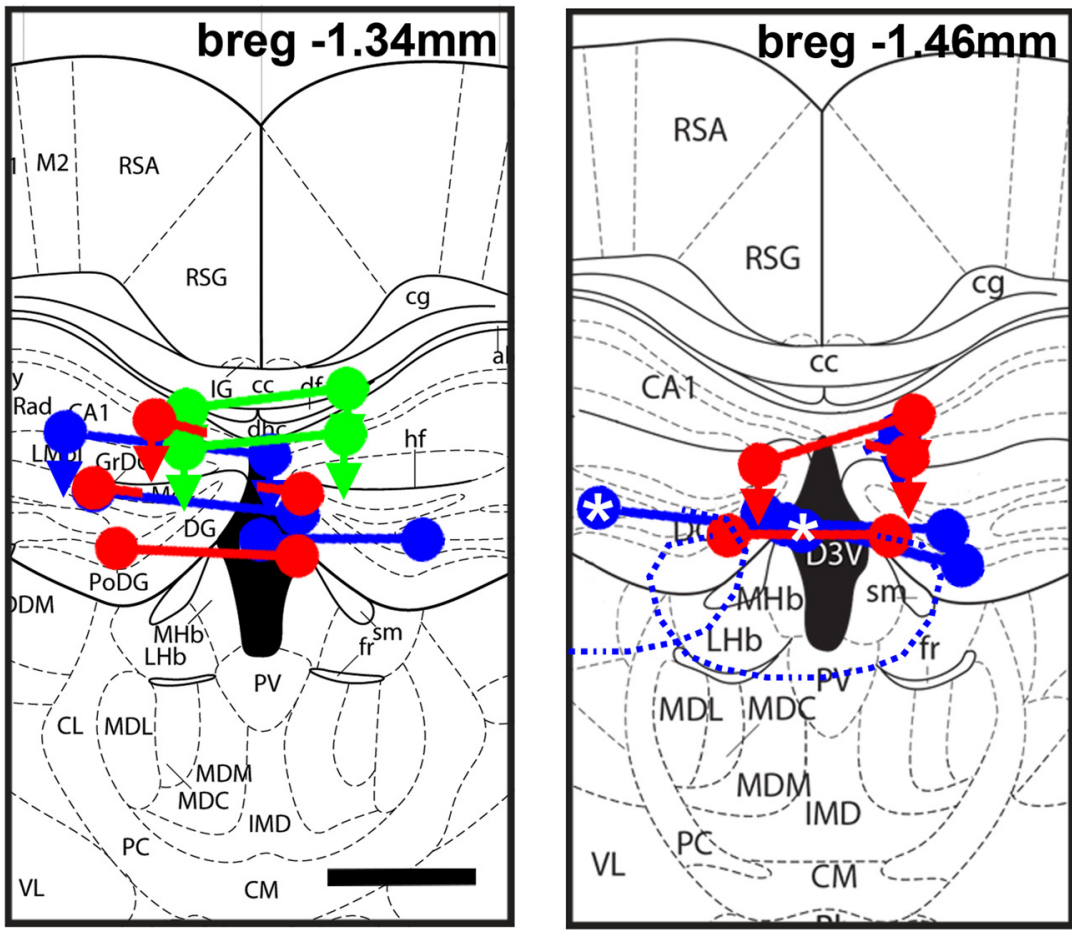

\section{Controls \\ $\mathrm{dMHb} \mathrm{bhR2}^{\mathrm{C}}$ \\ $\mathrm{vMHb}^{\mathrm{ChR2}}$}

\section{$1 \%$ transmittance}
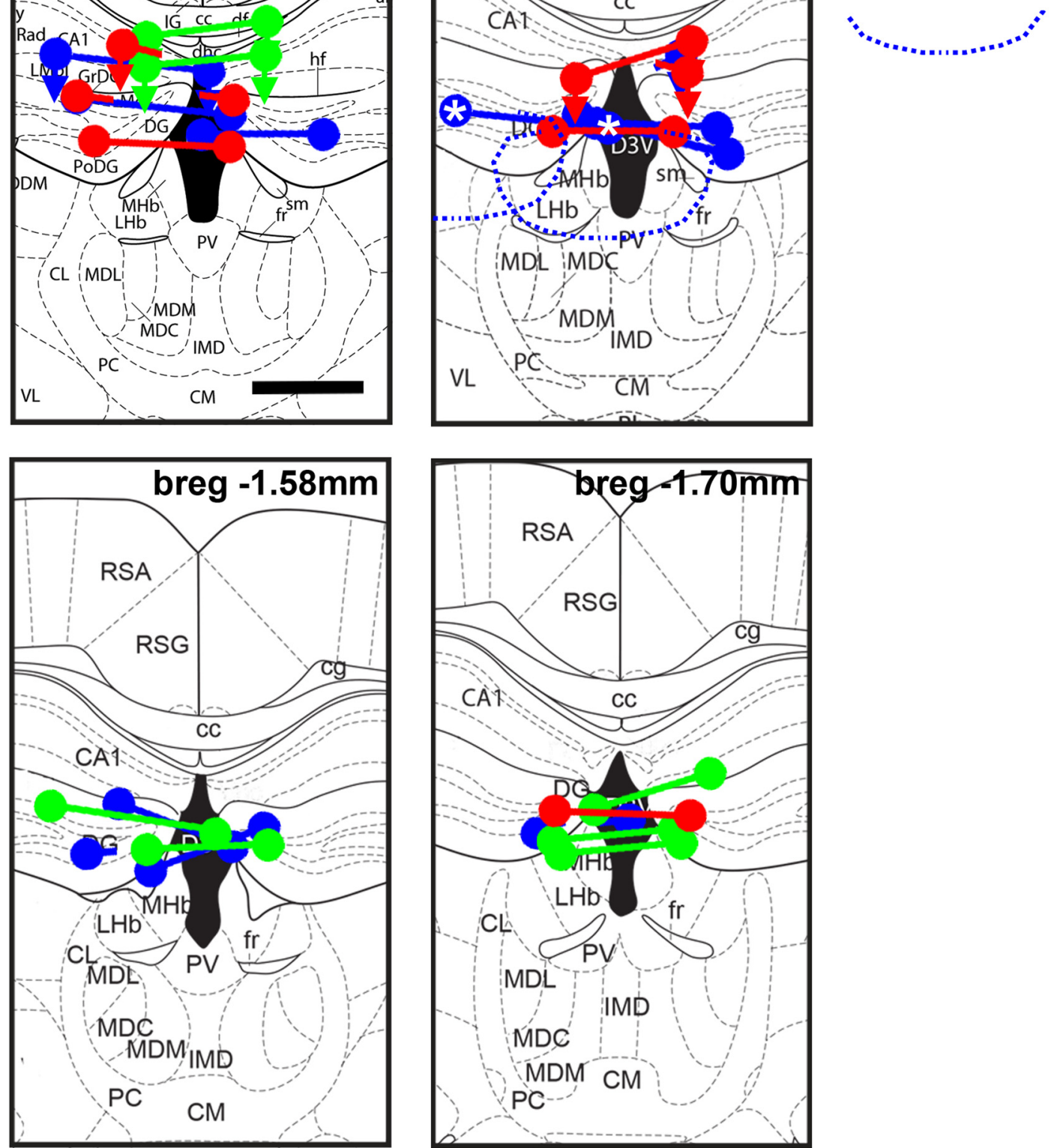

Figure 7. Placement of optical fibers in ICSS experimental mice. Mice with bilateral implanted fiber optic cannulas were perfused with a fixative at the conclusion of behavioral experiments and brains were examined for cannula placement. Fiber termini are shown on the level of a standard anatomical map (Paxinos and Franklin, 2001) closest to their rostrocaudal position at bregma -1.34, 1.46, 1.58, or $1.70 \mathrm{~mm}$. Nearly all of the cannulas thus were positioned within $\pm 0.2 \mathrm{~mm}$ of the intended coordinates at bregma $-1.6 \mathrm{~mm}$. Although some cannulas were displaced laterally, at least one of the two optical fibers terminated close to the habenula in every case. Fibers for $\mathrm{dMHb}^{\mathrm{ChR} 2}$ mice are shown in red, vMHb ${ }^{\mathrm{ChR} 2}$ mice are shown in green, and control mice are shown in blue. Connected dots indicate the probable ventral termini of the optical fibers from each case. In some cases, the right and left optical fibers mapped most accurately to different planes of section and are shown by disconnected dots. If the cannula track could not be followed to the terminus of the optical fiber, for instance due to termination in the ventricle, the most ventral position and the direction of the cannula track observed are indicated by an arrow. In all cases, the optical fibers were intact and transmitted light efficiently when examined postmortem after the experimental protocol. Scale bar, $0.5 \mathrm{~mm}$. Light was delivered through the bilateral cannula for a total output 
continued

of $8 \mathrm{~mW}$, corresponding to $4 \mathrm{~mW}$ per $100 \mu \mathrm{m}$ fiber or $509 \mathrm{~mW} / \mathrm{mm}^{2}$ at the fiber teriminus. Because some of the cannulas were displaced laterally, we used a published empirically derived model for the diffusion of $473 \mathrm{~nm}$ light in the mouse brain tissue to estimate the light intensity at target structures (Yizhar et al., 2011). The example laterally displaced cannula pair is indicated by an asterisk (bregma 1.46 view). The boundary of light penetration at $1 \%$ of that delivered at the fiber terminus is indicated by a dashed line $\left(\sim 5 \mathrm{mw} / \mathrm{mm}^{2}\right)$. Although one cannula is displaced laterally, the medial cannula is predicted to illuminate the entire habenula. The predicted intensity of light, $5 \mathrm{~mW} / \mathrm{mm}^{2}$, is sufficient to elicit reliable action potentials from dMHb neurons in brain-slice preparations.

gene, encoding the neuropeptides SP and neurokinin A (Bilkei-Gorzo et al., 2002). Tac1 mRNA, expression of which distinguishes the $\mathrm{dMHb}$ from the adjacent $\mathrm{vMHb}$ and $\mathrm{LHb}$, is nearly absent in $\mathrm{dMHb}^{\mathrm{CKO}}$ mice (Hsu et al., 2014). SP is also strongly expressed in dMHb fibers terminating in the lateral part of the interpeduncular nucleus in the ventral midbrain (Hsu et al., 2013). Thus, it is possible that the decreased TST immobility time observed in $\mathrm{dMHb}^{\mathrm{CKO}}$ mice results from a loss of Tac1 peptide signaling in the habenulopeduncular system; the effect of Tac1 gene deletion on the FST may reside in another pathway. NKB, the Tac2 gene product coexpressed with $\mathrm{SP}$ in the $\mathrm{dMHb}$ and its terminal fibers in the IP, may also play a role in these effects, but little is known about the
A
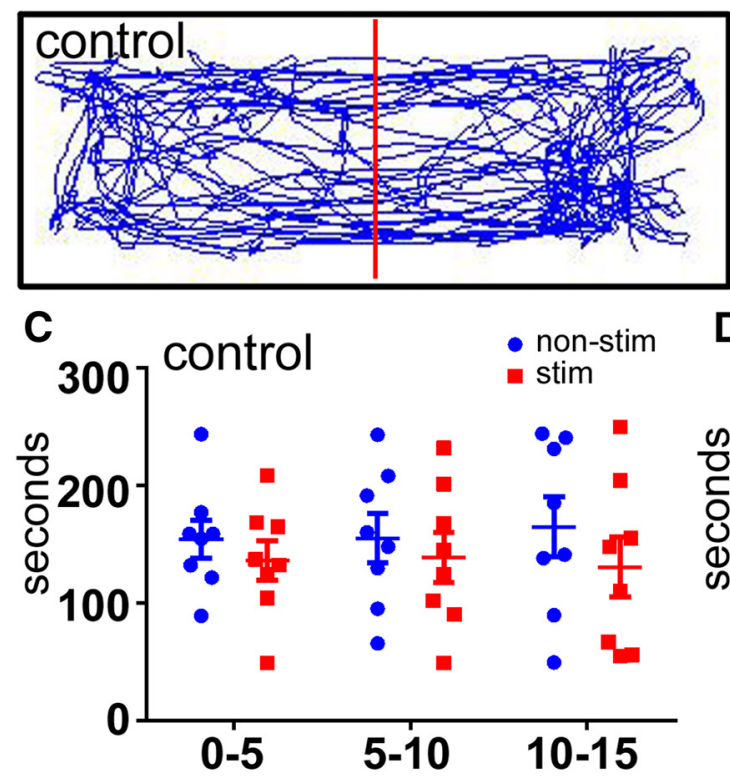

B
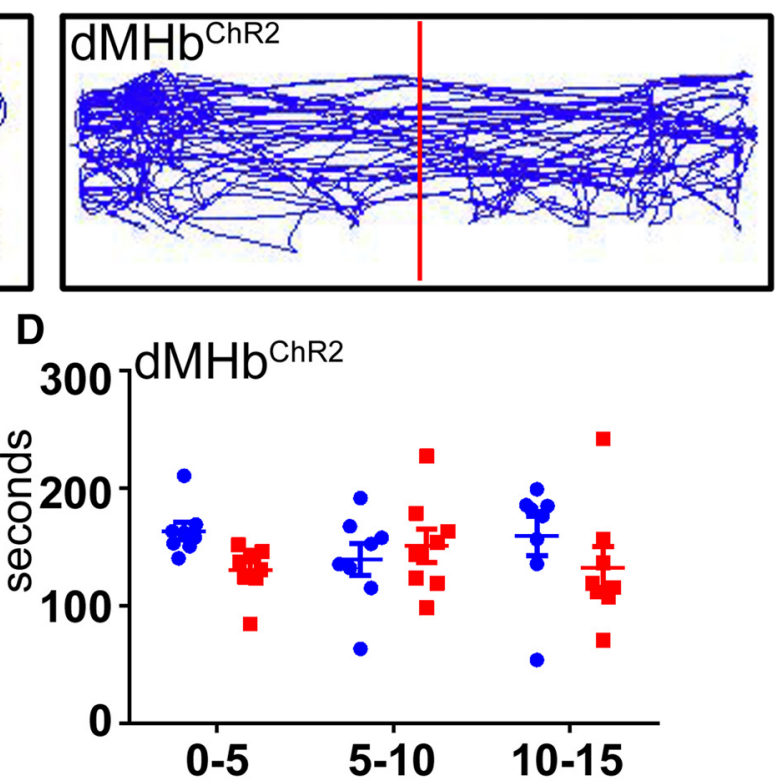

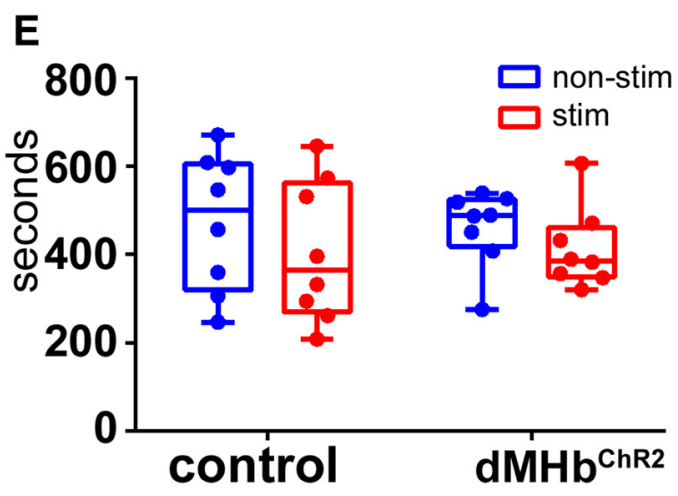

Figure 8. Real-time place preference. RTPP studies were conducted in a two-chamber place-preference box in which mice received light stimulation in one side, and could move freely between compartments. $\boldsymbol{A}, \boldsymbol{B}$, Example activity traces of control $(\boldsymbol{A})$ and $\mathrm{dMHb} \mathrm{b}^{\mathrm{ChR} 2}$ $(\boldsymbol{B})$ mice. Data are shown for an entire $15 \mathrm{~min}$ trial for a single animal of each genotype. $\boldsymbol{C}, \boldsymbol{D}$, Side preference of control $(\boldsymbol{C} ; n=8)$ and $\mathrm{dMHb}^{\mathrm{ChR} 2}$ mice $(\boldsymbol{D} ; n=8)$ displayed in 5 min bins over the course of a 15 min trial. The large variability in the side occupancy in the later intervals is likely to represent decreasing exploration during the course of the trial, with individual mice settling on one side of the chamber or the other, apparently without preference. $\boldsymbol{E}$, Summary of side occupancy for 15 min trial. No significant effect of side or genotype was observed. 
specific function of this peptide in the CNS. $\mathrm{dMHb}^{\mathrm{CKO}}$ mice show marked sensitization to the induction of learned helplessness. In contrast, ablation of the entire habenula attenuates the learned helplessness response (Amat et al., 2001), an effect which may be attributable to the LHb, because the induction of learned helplessness increases synaptic inputs to LHb neurons (B. Li et al., 2011). We expected to find that the sensitization to learned helplessness in $\mathrm{dMHb}^{\mathrm{CKO}}$ mice resulted from the marked loss of dMHb neurons in these animals. However, Pou $4 \mathrm{f} 1^{+/-}$mice, in which the $\mathrm{dMHb}$ is intact, also show sensitization to the induction of learned helplessness, demonstrating that Pou4f1 haploinsufficiency is sufficient to produce this effect. None of the other behavioral paradigms tested were affected by Pou4f1 haploinsufficiency.

The effect of Pou4f1 haploinsufficiency on learned helplessness was not anticipated in the light of prior work on the role of this transcription factor in neural development and gene regulation. Independent null alleles of Pou4f1 have been generated in at least three laboratories. Homozygous Pou4f1 null mutants die shortly following birth, probably from defects in brainstem motor systems (McEvilly et al., 1996), but Pou4f1 hemizygous mice are viable, fertile, and have no known developmental defects (McEvilly et al., 1996; Xiang et al., 1996; Quina et al., 2005). Furthermore, in the peripheral sensory nervous system, where Pou4f1 is a key developmental regulator, an autoregulatory mechanism has been identified which compensates for Pou4f1 gene dosage in heterozygous null embryos, nearly normalizing the expression of downstream regulatory targets (Trieu et al., 2003; Eng et al., 2004). Pou $4 \mathrm{f} 1$ is expressed in multiple CNS regions that are potential candidates for mediating the effect of haploinsufficiency on learned helplessness. These include the lateral habenula, superior colliculus (tectum), interpeduncular nucleus, red nucleus, and inferior olive (Fedtsova and Turner, 1995). Aside from the lateral habenula, however, the effect of these brain regions on mood regulation and stress response is not well characterized.

In a prior study, we have shown that $\mathrm{dMHb}^{\mathrm{CKO}}$ mice have markedly reduced voluntary wheel running activity (Hsu et al., 2014). This appears to be a specific deficit in exercise reinforcement, since basal locomotion is not affected. Although not generally used as a model of depression, WRA may interact with affective state and has been shown to produce an antidepressant-like effect in rats and mice (Greenwood et al., 2003; Duman et al., 2008). Thus, we conclude that the $\mathrm{dMHb}$ circuit clearly intersects pathways for depression-related behaviors across multiple models. These results are broadly consistent with the role of the $\mathrm{dMHb}$ in exercise reinforcement and intracranial self-stimulation reinforcement. However, ablation of the dMHb does not simply cause depressionrelated behaviors, nor does it prevent them in a way that encompasses all of the behavioral constructs used to model mood disorders and fear. As specific tools are used to dissect the underlying brain circuits for each of these mood-related behaviors, these pathways may be shown to impact depression-related behaviors by distinct mechanisms.

\section{References}

Amat J, Sparks PD, Matus-Amat P, Griggs J, Watkins LR, Maier SF (2001) The role of the habenular complex in the elevation of dorsal raphe nucleus serotonin and the changes in the behavioral responses produced by uncontrollable stress. Brain Res 917:118126. Medline

Bilkei-Gorzo A, Racz I, Michel K, Zimmer A (2002) Diminished anxiety- and depression-related behaviors in mice with selective deletion of the Tac1 gene. J Neurosci 22:10046-10052. Medline

Chourbaji S, Zacher C, Sanchis-Segura C, Dormann C, Vollmayr B, Gass P (2005) Learned helplessness: validity and reliability of depressive-like states in mice. Brain Res Brain Res Protoc 16:7078. CrossRef Medline

Cryan JF, Mombereau C (2004) In search of a depressed mouse: utility of models for studying depression-related behavior in genetically modified mice. Mol Psychiatry 9:326-357. CrossRef Medline

Cryan JF, Mombereau C, Vassout A (2005) The tail suspension test as a model for assessing antidepressant activity: review of pharmacological and genetic studies in mice. Neurosci Biobehav Rev 29:571-625. CrossRef Medline

Dejean C, Courtin J, Rozeske RR, Bonnet MC, Dousset V, Michelet T, Herry C (2015) Neuronal circuits for fear expression and recovery: recent advances and potential therapeutic strategies. Biol Psychiatry 78:298-306. CrossRef Medline

Duman CH (2010) Models of depression. Vitam Horm 82:1-21. CrossRef Medline

Duman CH, Schlesinger L, Russell DS, Duman RS (2008) Voluntary exercise produces antidepressant and anxiolytic behavioral effects in mice. Brain Res 1199:148-158. CrossRef Medline

Eng SR, Lanier J, Fedtsova N, Turner EE (2004) Coordinated regulation of gene expression by Brn3a in developing sensory ganglia. Development 131:3859-3870. CrossRef Medline

Fedtsova N, Turner E (1995) Brn-3.0 Expression identifies early post-mitotic CNS neurons and sensory neural precursors. Mech Dev 53:291-304. Medline

Gerfen CR, Paletzki R, Heintz N (2013) GENSAT BAC crerecombinase driver lines to study the functional organization of cerebral cortical and basal ganglia circuits. Neuron 80:1368-1383. CrossRef Medline

Greenwood BN, Foley TE, Day HE, Campisi J, Hammack SH, Campeau S, Maier SF, Fleshner M (2003) Freewheel running prevents learned helplessness/behavioral depression: role of dorsal raphe serotonergic neurons. J Neurosci 23:2889-2898. Medline

Harris JA, Hirokawa KE, Sorensen SA, Gu H, Mills M, Ng LL, Bohn P, Mortrud M, Ouellette B, Kidney J, Smith KA, Dang C, Sunkin S, Bernard A, Oh SW, Madisen L, Zeng H (2014) Anatomical characterization of Cre driver mice for neural circuit mapping and manipulation. Front Neural Circuits 8:76 CrossRef Medline

Heldt SA, Ressler KJ (2006) Lesions of the habenula produce stressand dopamine-dependent alterations in prepulse inhibition and locomotion. Brain Res 1073-1074:229-239.

Hikosaka O (2010) The habenula: from stress evasion to value-based decision-making. Nat Rev Neurosci 11:503-513. CrossRef Medline

Hsu YW, Tempest L, Quina LA, Wei AD, Zeng H, Turner EE (2013) Medial habenula output circuit mediated by $\alpha 5$ nicotinic receptorexpressing GABAergic neurons in the interpeduncular nucleus. J Neurosci 33:18022-18035. CrossRef Medline

Hsu YW, Wang SD, Wang S, Morton G, Zariwala HA, de la Iglesia $\mathrm{HO}$, Turner EE (2014) Role of the dorsal medial habenula in the regulation of voluntary activity, motor function, hedonic state, and primary reinforcement. J Neurosci 34:11366-11384. CrossRef Medline 
Keifer OP Jr, Hurt RC, Ressler KJ, Marvar PJ (2015) The physiology of fear: reconceptualizing the role of the central amygdala in fear learning. Physiology (Bethesda) 30:389-401. CrossRef Medline

Lammel S, Lim BK, Ran C, Huang KW, Betley MJ, Tye KM, Deisseroth K, Malenka RC (2012) Input-specific control of reward and aversion in the ventral tegmental area. Nature 491:212-217. CrossRef Medline

Lecourtier L, Kelly PH (2007) A conductor hidden in the orchestra? Role of the habenular complex in monoamine transmission and cognition. Neurosci Biobehav Rev 31:658-672. CrossRef Medline

Li B, Piriz J, Mirrione M, Chung C, Proulx CD, Schulz D, Henn F, Malinow R (2011) Synaptic potentiation onto habenula neurons in the learned helplessness model of depression. Nature 470:535539. CrossRef Medline

Li K, Zhou T, Liao L, Yang Z, Wong C, Henn F, Malinow R, Yates JR 3rd, Hu H (2013) $\beta$ CaMKII in lateral habenula mediates core symptoms of depression. Science 341:1016-1020. CrossRef Medline

Madisen L, Mao T, Koch H, Zhuo JM, Berenyi A, Fujisawa S, Hsu YW, Garcia AJ 3rd, Gu X, Zanella S, Kidney J, Gu H, Mao Y, Hooks BM, Boyden ES, Buzsáki G, Ramirez JM, Jones AR, Svoboda K, Han X, et al. (2012) A toolbox of Cre-dependent optogenetic transgenic mice for light-induced activation and silencing. Nat Neurosci 15:793-802. CrossRef Medline

Maier SF (1984) Learned helplessness and animal models of depression. Prog Neuropsychopharmacol Biol Psychiatry 8:435-446. Medline

Maier SF, Watkins LR (2005) Stressor controllability and learned helplessness: the roles of the dorsal raphe nucleus, serotonin, and corticotropin-releasing factor. Neurosci Biobehav Rev 29:829841. CrossRef Medline

Mar L, Yang FC, Ma Q (2012) Genetic marking and characterization of Tac2-expressing neurons in the central and peripheral nervous system. Mol Brain 5:3 CrossRef Medline

Maren S, Phan KL, Liberzon I (2013) The contextual brain: implications for fear conditioning, extinction and psychopathology. Nat Rev Neurosci 14:417-428. CrossRef Medline

Masugi $M$, Yokoi $M$, Shigemoto R, Muguruma $K$, Watanabe $Y$, Sansig G, van der Putten H, Nakanishi S (1999) Metabotropic glutamate receptor subtype 7 ablation causes deficit in fear response and conditioned taste aversion. J Neurosci 19:955-963.

Matsumoto M, Hikosaka O (2009) Representation of negative motivational value in the primate lateral habenula. Nat Neurosci 12:7784. CrossRef Medline

McEvilly RJ, Erkman L, Luo L, Sawchenko PE, Ryan AF, Rosenfeld MG (1996) Requirement for Brn-3.0 in differentiation and survival of sensory and motor neurons. Nature 384:574-577. CrossRef Medline

Paxinos G, Franklin KBJ (2001) The mouse brain in stereotaxic coordinates, 2nd Edition. San Diego, Calif. London: Academic.

Pham J, Cabrera SM, Sanchis-Segura C, Wood MA (2009) Automated scoring of fear-related behavior using EthoVision software. J Neurosci Methods 178:323-326. CrossRef Medline
Proulx CD, Hikosaka O, Malinow R (2014) Reward processing by the lateral habenula in normal and depressive behaviors. Nat Neurosci 17:1146-1152. CrossRef Medline

Quina LA, Wang S, Ng L, Turner EE (2009) Brn3a and Nurr1 mediate a gene regulatory pathway for habenula development. $J$ Neurosci 29:14309-14322. CrossRef Medline

Quina LA, Pak W, Lanier J, Banwait P, Gratwick K, Liu Y, Velasquez T, O'Leary DD, Goulding M, Turner EE (2005) Brn3a-expressing retinal ganglion cells project specifically to thalamocortical and collicular visual pathways. J Neurosci 25:11595-11604. CrossRef Medline

Rossi J, Balthasar N, Olson D, Scott M, Berglund E, Lee CE, Choi MJ, Lauzon D, Lowell BB, Elmquist JK (2011) Melanocortin-4 receptors expressed by cholinergic neurons regulate energy balance and glucose homeostasis. Cell Metab 13:195-204. CrossRef Medline

Rozeske RR, Valerio S, Chaudun F, Herry C (2015) Prefrontal neuronal circuits of contextual fear conditioning. Genes Brain Behav 14:22-36. CrossRef Medline

Soria-Gómez E, Busquets-Garcia A, Hu F, Mehidi A, Cannich A, Roux L, Louit I, Alonso L, Wiesner T, Georges F, Verrier D, Vincent P, Ferreira G, Luo M, Marsicano G (2015) Habenular CB1 receptors control the expression of aversive memories. Neuron 88:306-313. CrossRef Medline

Stamatakis AM, Stuber GD (2012) Activation of lateral habenula inputs to the ventral midbrain promotes behavioral avoidance. Nat Neurosci 15:1105-1107. CrossRef Medline

Steru L, Chermat R, Thierry B, Simon P (1985) The tail suspension test: a new method for screening antidepressants in mice. Psychopharmacology (Berl) 85:367-370. Medline

Tomida S, Mamiya T, Sakamaki H, Miura M, Aosaki T, Masuda M, Niwa M, Kameyama T, Kobayashi J, Iwaki Y, Imai S, Ishikawa A, Abe K, Yoshimura T, Nabeshima T, Ebihara S (2009) Usp46 is a quantitative trait gene regulating mouse immobile behavior in the tail suspension and forced swimming tests. Nat Genet 41:688695. CrossRef

Trieu M, Ma A, Eng SR, Fedtsova N, Turner EE (2003) Direct autoregulation and gene dosage compensation by POU-domain transcription factor Brn3a. Development 130:111-121. Medline

Xiang M, Zhou L, Nathans J (1996) Similarities and differences among inner retinal neurons revealed by the expression of reporter transgenes controlled by Brn-3a, Brn-3b, and Brn-3c promotor sequences. Vis Neurosci 13:955-962. Medline

Yamaguchi T, Danjo T, Pastan I, Hikida T, Nakanishi S (2013) Distinct roles of segregated transmission of the septo-habenular pathway in anxiety and fear. Neuron 78:537-544. CrossRef Medline

Yizhar O, Fenno LE, Davidson TJ, Mogri M, Deisseroth K (2011) Optogenetics in neural systems. Neuron 71:9-34. CrossRef Medline

Yoshikawa T, Watanabe A, Ishitsuka Y, Nakaya A, Nakatani N (2002) Identification of multiple genetic loci linked to the propensity for "behavioral despair" in mice. Genome Res 12:357-366. CrossRef Medline 